\title{
Immunity to Chlamydia trachomatis: lessons from a Gambian village
}

Chlamydia trachomatis is amongst the most prevalent bacterial pathogens. It affects principally mucosal epithelial surfaces in the eye and genital tract, and is a major cause of reproductive tract morbidity throughout the world, particularly in women. In the eye it causes trachoma, the commonest infectious cause of blindness, affecting at least 500 million people, of whom 7 million are blind as a consequence [1].

In its early stages, infection with $C$. trachomatis results in inflammation, with the formation of characteristic subepithelial follicles, but these changes are often mild, resulting in few if any symptoms. If the infection persists, or there are frequent reinfections, the inflammatory lesions are gradually replaced by fibrotic scarring, which leads to anatomical distortion of the eyelid or fallopian tube, eventually resulting in infertility or blindness in some cases [2]. These sequelae can be prevented by early treatment, but this can be achieved only by expensive screening programmes, as few infected subjects present with symptoms. Therefore, a vaccine against C. trachomatis is a high public health priority.

The age-specific prevalence of $C$. trachomatis infection suggests that protective immunity follows natural infection. The prevalence of genital infection is higher in younger age groups, and lower than expected among high risk populations such as commercial sex workers [3]. In trachoma endemic areas, it is unusual to find active, follicular disease in older age groups, or to be able to isolate the organism from the eyes of adults [4]. This observation encouraged large field trials of whole organism trachoma vaccines when it became possible to culture $C$. trachomatis in the 1960s [2].

Unfortunately, these vaccines provided, at best, transient protection in man and in some trials it appeared that vaccinated subjects had a higher incidence of disease [5]. Studies in the Taiwan monkey (Macaca cyclops) suggested that protection was serotype-specific, of short duration and mediated by antibody in the ocular secretions. Challenge with a different serotype led to more severe inflammation in immunised than in control animals, perhaps owing to cell-mediated delayed hypersensitivity [6]. Subsequent work in the cynomolgus monkey implicated a chlamydial heat-shock protein of $57 \mathrm{kDa}$ (HSP-60), homologous to the Gro-El heat-shock protein of Escherichia coli, in the pathogenesis of ocular inflammation [7].

We have studied the relationship between ocular antibody and the incidence and outcome of ocular chlamydial infection in the Gambian village of Jali, where trachoma is endemic. Peak prevalence of active disease is $c .40 \%$ in the $4-7$-year-old age groups. The total population is $c$. 900 , of whom about half are under 15 years old [8].

Tear samples for antibody assay were collected from the whole population in a series of cross-sectional studies. A Poisson regression model was used to examine the relationship between ocular antibody of the IgG and IgA classes to a local serotype B isolate of $C$. trachomatis and the acquisition and persistence of active disease, after controlling for age, sex and exposure to infection (defined as sharing a bedroom with an active case). The presence of antichlamydial antibodies of the IgG class was associated with an increased incidence and longer duration of disease, suggesting that these antibodies might enhance infection, either by blocking the attachment of neutralising antibodies of a different class, or by facilitating the uptake of $C$. trachomatis by epithelial cells. IgA antibodies reduced the incidence of infection, with few disease-free subjects having such antibodies although the difference was not statistically significant [9].

Serotype-specific monoclonal antibodies which recognise surface-exposed epitopes in the major outermembrane protein (MOMP) of $C$. trachomatis can neutralise infection in vitro [10]. Rapid mutation in the gene coding for this protein could explain the failure of local antibody to protect the population of Jali. Four strains of genotype A and two of genotype $\mathrm{B}$, each differing from the prototype strain by a single base pair were identified in a cross-sectional study. Two strains of genotype A and two of genotype B accounted for $>90 \%$ of infections, and this proportion remained stable over time, with the same genotype persisting in particular households [11]. Thus $C$. trachomatis can persist without the appearance of escape mutants in this highly exposed population in 
the presence of high levels of local antibody, indicating that antibody does not play a major role in protective immunity to ocular infection.

In two case-control studies to evaluate cell-mediated immune responses, the proliferative responses of peripheral blood mononuclear cells to whole elementary bodies of $C$. trachomatis, and to recombinant MOMP and HSP-60 were measured in: 29 subjects with scarring trachoma; 29 age, sex and location matched controls; 26 children whose active trachoma persisted for at least 6 months; and 21 children whose disease resolved during this period. Subjects with conjunctival scarring, and those with persistent inflammatory disease had reduced responses to all three chlamydial antigens compared to the control group $[12,13]$.

These results are consistent with studies in animal models that suggest an important role for cellmediated immunity in the clearance of chlamydial infection, mediated at least in part by the action of interferon- $\gamma$, which has anti-chlamydial activity in vitro and in vivo $[14,15]$. A T-helper (Th)-1 type of cell-mediated response, rather than a Th-2 type antibody response may be associated with clearance of chlamydial infection, as has been found in infections due to other intracellular pathogens such as Leishmania and Mycobacterium leprae [16, 17]. This is likely to have important implications for the development of a chlamydial vaccine.

D. MABEY, R. BAILEY

Department of Clinical Sciences, London School of Hygiene and Tropical Medicine,

Keppel St, London WCIE 7HT.

\section{References}

1. Dawson CR, Jones BR, Tarizzo ML. A guide to trachoma control. In: Programmes for the prevention of blindness. Geneva, World Health Organization. 1981.

2. Schachter J, Dawson CR. Human chlamydial infections. Littleton, MA, PSG Publishing Co. 1978.
3. Piot $P$, Van den Hoek JAR, Van Damme L, Laga $M$. Epidemiology and control of chlamydial infection. In: Orfila $\mathbf{J}$, Byrne GI, Chernesky MA et al. (eds) Chlamydial infections. Bologna, Societa Editrice Esculapio. 1994: 7-16.

4. Mabey DCW, Robertson JN, Ward ME. Detection of Chlamydia trachomatis by enzyme immunoassay in patients with trachoma. Lancet 1987; 2: 1491-1492.

5. Woolridge RL, Grayston JT, Chang IH, Cheng KH, Yang CY, Neave C. Field trial of a monovalent and of a bivalent mineral oil adjuvant trachoma vaccine in Taiwan school children. $A m J$ Ophthalmol 1967; 63: 1645-1650.

6. Wang S-P, Grayston JT, Alexander ER. Trachoma vaccine studies in monkeys. Am J Ophthalmol 1967; 63: 1615-1630.

7. Morrison RP, Lyng K, Caldwell HD. Chlamydial disease pathogenesis. Ocular hypersensitivity elicited by a genusspecific $57 \mathrm{kDa}$ protein. J Exp Med 1989; 169: 663-675.

8. Bailey R, Osmond C, Mabey DCW, Whittle HC, Ward ME. Analysis of the household distribution of trachoma in a Gambian village using a Monte Carlo simulation procedure. - Int J Epidemiol 1989; 18: 944-951.

9. Bailey RL, Kajbaf M, Whittle HC, Ward ME, Mabey DCW. The influence of local antichlamydial antibody on the acquisition and persistence of human ocular chlamydial infection: IgG antibodies are not protective. Epidemiol Infect 1993; 111: 315324.

10. Peeling RW, Maclean IW, Brunham RC. In vitro neutralization of Chlamydia trachomatis with monoclonal antobodies to an epitope on the major outer membrane protein. Infect Immun 1984; 46: 484488 .

11. Hayes LJ, Pecharatana S, Bailey RL et al. Extent and kinetics of genetic change in the ompl gene of Chlamydia trachomatis in two villages with endemic trachoma. $J$ Infect Dis 1995; 172: 268-272.

12. Holland MJ, Bailey RL, Hayes LJ, Whittle HC, Mabey DCW. Conjunctival scarring in trachoma is associated with depressed cell-mediated immune responses to chlamydial antigens. $J$ Infect Dis 1993; 168: 1528-1531.

13. Bailey RL, Holland MJ, Whittle HC, Mabey DCW. Subjects recovering from human ocular chlamydial infection have enhanced lymphoproliferative responses to chlamydial antigens compared with those of persistently diseased controls. Infect Immun 1995; 63: 389-392.

14. Byrne GI, Grubbs B, Marshall TJ, Schachter J, Williams DM. Gamma interferon-mediated cytotoxicity related to murine Chlamydia trachomatis infection. Infect Immun 1988; 56: 2023-2027.

15. Byrne GI, Grubbs B, Dickey TJ, Schachter J, Williams DM. Interferon in recovery from pneumonia due to Chlamydia trachomatis in the mouse. J Infect Dis 1987; 156: 993-996.

16. Sadick MD, Heinzel FP, Holaday BJ, Pu RT, Dawkins RS, Locksley RM. Cure of murine leishmaniasis with anti-interleukin 4 monoclonal antibody. Evidence for a $\mathrm{T}$ cell-dependent, interferon gamma-independent mechanism. J Exp Med 1990; 171: $115-127$.

17. Yamamura M, Uyemura K, Deans RJ et al. Defining protective responses to pathogens: cytokine profiles in leprosy lesions. Science 1991; 254: 277-279. 